\title{
ULRICH HAARMANN
}

Arabic in speech, turkish in lineage

Mamluks and their sons in the intellectual life of fourteenth-century Egypt and Syria 


\author{
ARABIC IN SPEECH, TURKISH IN \\ LINEAGE: MAMLUKS AND THEIR SONS \\ IN THE INTELLECTUAL LIFE OF \\ FOURTEENTH-CENTURY \\ EGYPT AND SYRIA*
}

\author{
ULRICH HAaRMANN \\ UNIVERSITÄT FREIBURG IM BREISGAU
}

I

In spite of rich historiographical and epigraphical data it is difficult to evaluate the cultural and intellectual achievement of Mamluks and of their offspring, the so-called awläd al-nās, in fourteenth-century Egypt and Syria in comparison to, and contrast with, non-Mamluks. There are no preliminary quantitative analyses of fourteenth-century biograms, and even if they existed, such statistics would be of limited value, if not outrightly false. We still depend to a very large degree on the information of the local, non-Mamluk, 'ulam $\vec{a}$ ' authors as far as the intellectual life of the period is concerned, even if the study of archival materials - and especially of endowment deeds giving details of the academic curriculum and titles of textbooks and selected private documents, for example death inventories, presenting the library holdings of a deceased scholar - will help us to place this information in the right perspective. The nonMamluk scholars of the time tended to minimize the contribution of alien, Mamluk authors to their own contemporary civilization. Therefore an analysis of this bias should precede

* The first results of research pursued for this article were presented, under the title of 'Mamluks and awläd al-näs in the intellectual life of fourteenth-century Egypt and Syria', at the Seventh Oxford-Pennsylvania History Symposium in Oxford in the summer of 1977; the papers of this conference were never published, without any explanation as to the reasons for this ever being given by the editor who had volunteered to take over this task. The present article was given its final form in spring 1987 during my stay at the Institute for Advanced Study in Princeton. 
any study that aims at a patterning of Mamluk and non-Mamluk cultural activities.

The contemptuous attitude of Arab 'ulama' towards the Turks and their achievements outside the domains of their proper fad $\vec{a} i l$, such as warfare, horsemanship and physical attractiveness, has a venerable tradition in Islam that goes back at least to al-Jāhiz and al-Mas ${ }^{e} \overline{\text { din. }}{ }^{1}$ In the Mamluk period, moreover, only a very few Arab authors were ready to appreciate, in writing, the secular merits of the Turks who had vanquished the Mongols, and thus saved Islam altogether. One of them is Sultan Baybars' court physician Ibn al-Nafis (d. 687) I 288), who eulogizes the courage and stamina of the savage Mamluks. ${ }^{2}$ Another is Abū Hāmid al-Qudsī (d. 888/1483) who, disillusioned about the conceitedness and unbearable arrogance of his 'ulam $\vec{a}$ compeers, ${ }^{3}$ lauds the Mamluk Turks as the 'salt of Egypt' who give their energies and even their lives in the service of Islam and its followers; they protect the ra iyya; and even the scum of the people, the $q u^{i} r$, will pride themselves on Mamluk tutelage. ${ }^{4}$ Yet these and similar compliments certainly did not include any appreciation of the Mamluk contribution to the realm of culture.

The question of an indigenous Mamluk court culture simply did not appear to be relevant to the contemporary 'ulamä', even

1 Some basic information on the image of the Turk in classical Arabic literature can be found in C. T. Harley Walker, 'Jahiz of Basra to al-Fath ibn Khaqan on the exploits of the Turks', JRAS (I91 5), 631-97; T. Kowalski, 'Die ältesten Erwähnungen der Türken in der arabischen Literatur', Körösi Csóma Arcbivum 2 (1926-31), 38-4I ; E. Mainz, 'Die Türken in der klassischen arabischen Literatur', Isl. 2 I (1933) 279-85. See also Ignaz Goldziher's comments on 'Traditions about the Turks' in his Muslim Studies, tr. S. M. Stern (London 1967), I, 245-6; Haarmann, 'Ideology and History, Identity and Alterity: The Arab Image of the Turk from the 'Abbasids to Modern Egypt', IJMES 20 (1988) 1 $75-96$.

${ }_{2} \mathrm{M}$. Meyerhof and J. Schacht, The Theologus Autodidactus of Ibn al-Nafĩs (Oxford 1968), 42-6 Arabic text, 66-70 English translation.

3 See my "Rather the Injustice of the Turks than the Righteousness of the Arabs" - Changing "ulama $\vec{a}$ Attitudes towards Mamluk Rule in the Late Fifteenth Century', to appear in $S I$ (1988).

${ }_{4}$ Abū Hāāmid al-Qudsī, K. Duwal al-isläm al-sharīfa al-babiyya wa-dbiker mā zabara lī min bikeam Alläb al-kbafiyya fī jalb țǟifat al-Atrâk ilä 'l-diyār almisriyya, listed in Brockelmann, GAL, S II, $S I-2$. On the author and this work, see Subhi Labib in Isl. 56 (1979) I1 7-20; Michael Cook, 'Abū Hāmid al-Qudsī (d. 888/1483)', JSS 28 (I983) 85-97; Haarmann, " Rather the injustice of the Turks"', passim. 


\section{ARABIC IN SPEECH, TURKISH IN LINEAGE}

though some of these were of Mamluk extraction. ${ }^{5}$ When Ibn Hajar describes the life of the Mamluk Uzdamur al-Kāshif, he readily states that he was brutal, blood-thirsty and cunning quite becoming for a Mamluk, one would like to add sarcastically - but that, surprisingly enough, he had memorized the complete maqämāt of al-Harìri and other poems. ${ }^{6}$ Other Mamluks who distinguished themselves in learning or patronage are described, as we shall see again and again, as rare exceptions in their own race.

The Mamluks remained labelled as military men who were not susceptible to, let alone creative in, the refinements of art and literature. Too rigorously the Turkish crafts, such as furusiyya and archery, were contrasted with the Arabic, that is, religious sciences. ${ }^{7}$ A similar structural prejudice along ethnic lines against the 'men of the sword' has been observed in Safawid Persia, where the Tajiks, the Iranians, held that 'the job of the Turks was to do the fighting, but [that] they were not expected to possess much intelligence'. 8 Likewise, the same condescending attitude was characteristic of the relationship between the ilmiyye and the Janissaries in the Ottoman empire in the sixteenth century; scholarly achievement by a qul was dismissed as a 'good try', an accomplishment profoundly unexpected and unlikely to be repeated. ${ }^{9}$

The 'ulama' of the Mamluk period declared culture and science their own proper domain. The alien Turkish-Mamluk mukalwatün, 'cap-bearers', who remained beyond their control, were not supposed to distinguish themselves in learning; they were only expected to provide the necessary political stability for, and to give their financial support to, the religious-academic system. Just as these strangers with their disputed

5 When stating that 'no study of Mamluk "court culture" has yet been made', I. M. Lapidus seems to neglect these fundamental impediments to our knowledge of this subject. See his Muslim Cities in the Later Middle Ages (Cambridge, Mass. I967), 44.

6 Al-Durar al-kämina fĩ a jaän al-mi’a al-thämina, ed. Muhammad Sayyid Jādd al-Haqq (Cairo I 385 ), I, 378.

7 W. Popper, 'Sakhāwî̀'s criticism of Ibn Taghrī Birdī', Studi Orientalistici in onore di Giorgio Levi della Vida (Rome 1956), In, 378.

8 R. Savory, 'The Qizilbāsh, Education and the Arts', Turcica 6 (1975) 169.

9 Professor Cemal Kafadar of Princeton kindly pointed out to me the case of the Albanian Janissary Luții Pasha, who flourished in the middle of the sixteenth century and left numerous scholarly works. 
legitimacy monopolized the political and economic power in the state, so active scholarship was to remain reserved to the muta ammimun, the indigenous 'turban-bearers', the 'men of religion'. ${ }^{10}$ By insidiously declaring the full command and correct pronunciation of Arabic as the first criterion of culture, ${ }^{11}$ they barred most Mamluks from their own holy precinct, because these Mamluks continued to use Turkish as the language of the army and must have experienced great difficulty in shaking off completely their alien accent when they spoke Arabic. Due to this bias, we must assume that many cultural achievements of Mamluks were simply passed over and suppressed. The 'ulam $\vec{a}$ ' who regarded themselves as custodians of the values of the traditional society showed little curiosity about the world of the Mamluks, because it was intrinsically pagan, Turkish or Mongol, and therefore not deemed suitable for recording in the hallowed genre of Islamic writing. 'Ulam $\vec{a}$ continued to write about 'ulam $\vec{a}$ ' and for 'ulam $\vec{a}$ ', paying little or no attention in their works to all those who stood outside their own circles.

One should add that this predominantly negative image of the uncouth and uncultured Turk has lamentably remained virulent into the modern period. ${ }^{12}$ Turks and Mamluks were held mainly responsible for the downfall of manners and culture in the Arabic-speaking Middle East. They provided a facile excuse for the desiccation of their proper cultural heritage. Yet the stubborn resistance of the 'ulam $\vec{a}$ ' to any serious and prolonged intellectual contacts with their Turkish lords and neighbours may well have been a significant factor in accelerating their descent into irretrievable mediocrity. The Mamluks could have given more to contemporary society than they were allowed to. It was not their fault alone that the Mamluk court,

10 A. Schimmel, Studien zur Kulturgeschichte des mittelalterlichen Ägypten, typescript (Berlin 1944), I $21-2$, and L. A. Mayer, Mamluk Costume (Geneva I952), 28, explain the terms mukalwat 'kallawta-bearer' and muta'ammim 'turban-bearer' in this political context.

11 Schimmel, 'Kalif und Kadi im spätmittelalterlichen Ägypten', WI 24 (1942) 18. One contender for the office of caliph failed because he was unable to differentiate between läm and $r \vec{a}$ ' in his speech.

12 See my article, 'Ideology and history ...', passim. The prolific and original writer Husayn Fawzi stands for the validity of this attitude even in our time, when he sums up the role of the Turks in the history of Egypt in his treatise Sindibäd missri (Cairo 1969) 347: wa-kull mä tajlibubü aswäq alnikbāsa 'alä 'l-sharq al-adnā min ajnās al-Turk. 
even during the reign of great sultans, did not attract outstanding figures of the time who - as in the heyday of the Seljuqs invoked the principles of a just Islamic ruler and generated a splendid cultural aura of their own that would inspire others to join. The local intellectuals shunned and even abhorred contacts with the Mamluks. Al-Suyutị̂'s case is typical. The religious prohibition of yielding to worldly sovereigns gave him, at the end of the fifteenth century, a welcome pretext for not paying his respects to Sultan Qāyitbāy. ${ }^{13}$ Qāyitbāy was a highly cultured ruler. He had the grave fault, however, of writing religious poetry, not only in Arabic, but also in barbaric Turkish. ${ }^{14}$

With these impediments in mind, the 'culture' of the Mamluks will remain largely inaccessible and elusive to us, at least as long as no new materials of different provenance are opened up and the available copious sources have not been studied systematically. The present study, which is based mainly on selected biographical material, particularly on the published volumes of al-Ṣafadī's al-Wäfï bi 'l-wafayāt ${ }^{15}$ and Ibn Hajar's prosopography of the fourteenth century, al-Durar al-kāmina, can therefore offer only tentative conclusions. Yet the culture of the Mamluks deserves such an attempt; it had an original and intercultural perspective and sometimes contrasted favourably with the parochial activities of the Egyptian (and, though less so, Syrian) 'ulama' whose curiosity was stifled by various selfimposed dogmatic restrictions.

In what follows, the Mamluks and then, in the second place, the awläd al-nās, will be introduced as actors on the cultural stage of fourteenth-century Egypt and, to a lesser degree, also of Syria. In Syria, the indigenous scholarly tradition remained more vigorous than in Egypt in Mamluk times. Attention must be given not only to the halls of the sultans and their grandees as places of learning and art, but also to the cultural life in the houses of the lowly Mamluk private soldiers (jund $\vec{\imath}$ ) who often quite understandably sought and found comfort for a

13 E. M. Sartain, Jaläl al-dīn al-Suyūtīi (Cambridge 1975), I, Biography and Background, 86-91.

14 J. Eckmann, 'Die kiptschakische Literatur', Pbilologiae Turcicae Fundamenta, II (Wiesbaden 1965), 299, gives a list of Sultan Qāyitbāy's writings.

15 Vols I-XVII, XXII so far published (Wiesbaden 1962-84). 
disappointing military and public career in the bliss of piety, poetry, and scholarship. ${ }^{16}$

One important concession has to be made. Religious architecture, a field in which the Mamluks and also some awläd al-näs (such as the grandsons of Tankiz, ${ }^{17}$ al-Nāșir's infelicitous Syrian viceroy) distinguished themselves as patrons and donors, will be excluded from this survey. Mamluk architecture and patronage have been studied thoroughly, ${ }^{18}$ and even the ideological and religious motives behind the building mania of Mamluk grandees have been tentatively interpreted. ${ }^{19}$

\section{II}

We do not know much about the personal scholarly and cultural interests of Mamluk sultans and amirs in the fourteenth century. In the fifteenth and sixteenth centuries, the period of the blossoming of Mamluk-Turkish court culture, when the Mamluk newcomers were already deeply imbued with their native Turkish cultural background, our knowledge is far more complete. Yet the paraphernalia of the 'liberal arts' education with which almost every Mamluk, from the thirteenth century on, was confronted, are known. We learn from al-Maqrizi (d. 845/1442) in a much-quoted passage of his Kbitat that the kuttäbiyya, the young Mamluks who were garrisoned in the tibāq (barracks) of Cairo, were instructed in Arabic, calligraphy and

16 Al-Maqrīzī, al-Mawā'iz wa 'l-i"tibär bi-dbikr al-kbitat wa 'l-ätbār (Cairo 1853-4) (= al-Kbitat), II, 2I4, describes the military and intellectual training of the Mamluks. Victims of these frustrations are recorded in the biographical dictionaries: Āqqūsh al-Baysarī, who lived to become almost one hundred years old as a trooper ( $j$ undi $)$, laments his misfortune in a poem written on a wooden clog (qabqäb); see Ibn Hajar, I, 426; al-Șafadī, rx, ed. J. van Ess (Wiesbaden 1974), 339f. See also below nn. 79 and 80.

17 Ibn Șașrā, A Cbronicle of Damascus 1389-1397, ed. and tr. W. Brinner (Berkeley-Los Angeles 1963), I, I 44 (and n. 907), I 78-80; II, I I6, I33-5 (fols I I6a, I 36a-137b). Tankiz's daughter was one of al-Malik al-Nāṣir Muhammad's wives and the mother of the Sultan Șālih; cf. al-Ṣafadī, xvi, ed. Wadād al-Qāọī (Wiesbaden 1982). 271, 1. I2. Tankiz's death in disgrace had impaired neither her own nor her brothers' careers for these last had been promoted to the amirate at a very young age, cf. al-Safadī, x, ed. Ali Amara and Jacqueline Sublet (Wiesbaden 1979), 422-3.

${ }^{18}$ It will suffice here to give the names of K. A. C. Creswell, Ch. Kessler, M. Meinecke, J.M. Rogers, and G. T. Scanlon, all of whom are or were associated with the American University in Cairo.

19 R.S. Humphreys, 'The Expressive Intent of the Mamluk Architecture of Cairo: a Preliminary Essay' SI 35 (1972) 69-119. 
the fundamentals of the religious sciences, even before they underwent the rigorous training in the chivalrous arts and were affranchised. ${ }^{20}$ Abū Hāmid al-Qudsī (d. 888/r483) mentions in his treatise on 'God's wisdom of bringing the Turks to the land of Egypt' that the classical - that is, thirteenth- and early fourteenth-century - non-military curriculum of the Mamluk novice consisted of four cycles of five years each. ${ }^{21}$ Even if all the figures which this author gives in this work are probably vastly exaggerated, we can be sure that the civil education lasted long enough to give the young kuttäbi the opportunity to lay the basic foundations also for a future scholarly career.

Barbara Flemming has discovered a considerable number of transcripts of Turkish and Arabic works (the latter sometimes with an interlinear Turkish translation) which seem to have been prepared by young Mamluks during their stay in the barracks. ${ }^{22}$ The scribes, with the rather clumsy hands of youngsters, not only give their Turkish names (and the name of their ustädh and prospective manumitter), but also indicate the barracks in which they were stationed. She convincingly argues that these volumes, with ornate bibliophile frontispieces and a striking similarity to each other, were exercise books of the pupils that were later to become part of their masters' libraries. These texts give a glimpse of the syllabuses and the teaching materials that were used in class. The topics of the transcribed texts range from the qisas al-anbiy $\vec{a}^{\prime}$, religious poetry and prayers to tracts on the Mirrors for Princes theme - certainly no inappropriate subject-matter for future members of the political and military élite. For the present limited purposes, it is unfortunate that all these precious documents pertain to the closing days of the fifteenth and the early sixteenth century. We do not know, so far, whether this practice of using one's young military slaves as copyists for the private library goes back to the pre-Circassian period.

Al-Maqrīin sums up the chances for a Mamluk to achieve prominence in letters and scholarship on the basis of his liberal training. He remarks in an animated sentence in which he seems to address the disenchanted Mamluk private soldier who did not rise to the aspired high rank: 'At least he received a good

20 Al-Kbițat, II, 213.

21 Duwal al-islam, as quoted by S. Labib in Isl. 56 (1979) I I 7-20.

22 'Literary Activities in Mamluk Halls and Barracks', Studies in Memory of Gaston Wiet, ed. M. Rosen-Ayalon (Jerusalem I 977), 249-60. 
education. His manners were enhanced and respect for Islam and its adherents was implanted in his heart'. He goes on to say that a few among the Mamluks 'managed even to reach the rank of a knowledgeable jurist or of an $a d i \bar{b}$ and poet or of a capable accountant'. ${ }^{23}$

The further intellectual career of an affranchised Mamluk depended on his piety, the profundity of his training and, quite distinctly, on his opportunities and on the cultural atmosphere in which he grew up. Mamluk culture, to use this term, could not flourish in isolation. It is certainly no mere accident that Alțunbughā al-Jāwulī, Aruqtāay, and Aytamish, three of the most prominent fourteenth-century Mamluk amirs who were interested in literature and learning, belonged all to one and the same circle, to which also their common biographer, Khalil b. Aybak al-Șafadī, had access. As will be discussed in detail later, the awläd al-nās, the sons and grandsons of Mamluks - such as al-Safadi - played a crucial role in the formation of this Mamluk culture. They were the given mediators between the local establishment of 'ulam $\vec{a}$ ' and $u d a b \vec{a}$ ', and the Mamluks. So Sultan Hasan, an exceptionally religious ruler (in prison he had studied al-Bayhaqīs (d. 458/ro66) Daläil al-nubuwwa) certainly owed much of his knowledge and his manners to the awläd al-nās environment in which he grew up, which he never abandoned, and of which he was himself, in a sense, a member, being the grandson of a full-fledged, first-generation Mamluk. ${ }^{24}$

Sultan Hasan, with his vivid cultural interests that are epitomized in his magnificent madrasa below the Cairo citadel, remained an exceptional figure in the Bahri period. Among his predecessors on the throne we do not find the same active involvement in scholarship, although at least Sultan Làjīn

23 Al-Kbitat, II, 21 3-14. See also Schimmel, Studien, 44-5, 48. D. Ayalon, L'Esclavage du Mamlouk (Jerusalem 1951), I3-14, omits this passage in his French translation.

${ }^{24}$ Ibn Hajar, Ir, I24f.; see also the remark in Robert Irwin, The Middle East in the Middle Ages. The Early Mamluk Sultanate 1250-1382 (London 1986), 139. On al-Bayhaq'i's work, see the references given in Brockelmann, GAL, I, 363 . Sultan Hasan's prestige as a pious ruler, contrasting most favourably to his brothers, persisted long after his death; see Ayalon, 'The Eunuchs in the Mamluk Sultanate', Studies in Memory of Gaston Wiet, 293, n. 122. For Hasan's uneventful life before his second accession to the throne see, however, al-Ṣafadī, xII, ed. Ramaḍān 'Abd al-Tawwāb (Wiesbaden 1979), 266-7. 
(696-8/1 296-9) ${ }^{25}$ and Sultan Baybars II al-Jāshnkīr (708-9/ r $309-10)$ - as will be discussed below - also sought the company of scholars and promoted the arts. Their periods of rule were short, far too short to set new standards. Nothing was reminiscent in Cairo of the royal penmanship flourishing at the Ayyubid provincial court of Hamāh at the same time.

Beginning approximately with the change from Bahrī to Burji rule, a new chapter in the cultural history of the Mamluk class began. From Barqūq to the closing days of the Mamluk régime in the early sixteenth century, the sultan and his court tended to participate actively in the religious and cultural life of their time, as patrons or even as writers in their own right. ${ }^{26}$ The ties between the court and local, mainly mystical, religious leaders became stronger. Barqūq precipitated his process with his efforts to harmonize 'ilm and tasawwuf at least in all those institutions that were under his control. ${ }^{27}$ Sultan Khushqadam became known for his veneration of Egypt's great thirteenthcentury saint, Ahmad al-Badawi of Tanțā,28 and Sultan Qāyitbāy, himself a writer of mystical verse, did not hesitate to support the cause of the Sufi poet Ibn al-Färid (d. 632/1235), whose orthodoxy was denied by rigorist theologians. ${ }^{29}$

25 Al-Nuwayrī, Nibäyat al-arab fĩ funūn al-adab, praises Sultan Lājīin's friendly contacts with muta ammimün and lowly people alike; see M. S. Elham, Kitbuğä und Läğiñ. Studien zur Mamluken-Geschichte nach Baibars al-Manșürī und an-Nuwairi (Freiburg 1977), 266f. German translation, 83, 1l. 2-3 Arabic text.

${ }_{26}$ On this neglected subject, see the contributions by Schimmel, 'Sufismus und Heiligenverehrung im spätmittelalterlichen Ägypten', Festschrift Werner Caskel (Leiden 1968), 274-88, esp. 274f.; eadem, 'Some Glimpses of the Religious Life in Egypt during the later Mamluk period', IS 7 (1965) 353-92. B. Flemming, "Šerif, Sultan Gaurī und die "Perser"', Isl. 45 (1969) 81-93; eadem, 'Literary Activities' (see n. 22); eadem, 'Aus den Nachtgesprächen Sultan Gaurīs', Folia Rara. Verzeichnis der orientalischen Handscbriften in Deutschland, Supplementband I9 (Wiesbaden 1976), 22-8; eadem, 'Zum Stand der mamluk-türkischen Forschung', ZDMG, Supplementband III, 2. XIX. Deutscher Orientalistentag (Wiesbaden 1977), I I 6-64. J. Eckmann, 'Die kiptschakische Literatur' (see n. I4), $299 \mathrm{f}$.

27 On Barqūq's kebannaqāb and the stipulations regarding the Sufi inmates, see now F. Jaritz, 'Auszüge aus der Stiftungsurkunde des Sultans Barqũq', in Saleh Lamei Mostafa, Madrasa, Hānqäh und Mausoleum des Barqūq in Kairo (Abhandlungen des Deutschen Archäologischen Instituts in Kairo, Islamische Reihe, 4), (Glückstadt 1982), I I 7-78; Haarmann, 'Mamluk Endowment Deeds as a Source for the History of Education in Late Medieval Egypt', Al-Abbäth 28 (Beirut I980) 3 I-47.

28 Schimmel, 'Sufismus', 275.

29 Sartain, Jalāl al-dìn al-Suyüțī, I, 54f.; Schimmel, 'Sufismus', $287 \mathrm{f}$. 
Another important development dates back to the rule of Sultan Barquiq: the efflorescence of Mamluk-Turkish literature in Syria and Egypt. We have Arabic-Turkish word-lists and grammars that were compiled as early as the beginning of the fourteenth century. These manuals were written in Qipchaq Turkish, the vernacular of the bulk of Bahri and also, together with Circassian dialects, of Burji Mamluks, and served the purpose of facilitating the communication between the Mamluks and their subjects and non-Mamluk aides. But these texts were not literature in the strict sense of the word. In Barqūq's time Turkish writers began to appear in Egypt and Syria. Those coming from the Volga wrote in Qipchaq, those coming from Anatolia or Azerbayjan - and they were the majority, particularly in the fifteenth and sixteenth centuries - used Oghuz, that is, Ottoman Turkish. According to Flemming, the first representative of this new Turkish literary school in the Mamluk state was ' Umar al-Darīr from Eastern Anatolia. ${ }^{30} \mathrm{He}$ began his 'Life of the Prophet' (Siyer) in 778-9/1 377. Berke Faqih, the second great name in Mamluk Turkish writing, completed his rhymed epilogue to Quțb's (d. after 742/I 341-2) Turkish version of Nizāmī's mathnawi in $785 / 1383$; four years later he translated, in Alexandria, an Arabic legal tract, Irshād al-mulük wa "l-salātinn, into Turkish. Both Berke and Sayf-i Sarāyī (d. after 793/r39I), who rendered Sa dì's Gulistān into Turkish in 792/1 390, came from the lands of the Golden Horde. ${ }^{31}$ Hamza al-Turkumānī, a wafidi from the Eastern lands, had brought the stories of the Shäbnama and of the Kings of Old Persia - together with important information on the Īlkhāns - to Tankiz, the Syrian viceroy, as early as the twenties and thirties of the fourteenth century and had harvested the very complimentary sobriquet of Rustam. ${ }^{32}$ After 1400 , and especially after 1450 , numerous literary and didactic works were written, or commissioned, at Mamluk courts. ${ }^{33}$ The poems by the Sultans Qayitbāy, the young Muhammad b. Qāyitbāy and Qānșawh al-Ghawrī, are the best known, yet certainly not the sole specimens.

30 'Zum Stand der mamluk-türkischen Forschung', I I 57 f.; eadem, 'Literary Activities', 252.

31 Eckmann, 'Die kiptschakische Literatur', 298-30r.

32 Al-Ṣafadī, xIIr, ed. Muhammad al-Hujayrī (Wiesbaden I982), r 88-9.

33 In this context, one must mention TToghan Shaykh's Turkish translation of al-Mãwardī's manual of government al-Ableâm al-sultānìyya; it had been commissioned by Sultan Qāyitbāy. See Brockelmann, GAL, I, 386. 
But even in this period Turkish never dislodged Arabic as an alternative language in Mamluk writing. The cultured great dawāäar Yashbak min Mahdī (d. 885/1480) wrote both Turkish verse and an Arabic treatise on the descent of the Prophet. ${ }^{34} \mathrm{He}$ owned a precious set of al-Șafadì's many-volume biographical dictionary al-Wäfí bi ' l-wafayāt. His biographer and close associate Ibn Ajā (d. 881/1476) was also bilingual. His Futūb alShäm, a Turkish version of al-Wāqidī's history in 'twelve thousand verses', stands besides numerous books in Arabic. ${ }^{35}$ Sultan Qānșawh al-Ghawrī, the celebrated patron of Turkish letters of the last days of the Mamluk kingdom, left us excellent poems also in Arabic. ${ }^{36}$

Before the arrival of Turkish literature in Mamluk Egypt and Syria, that is, during most of the fourteenth century, however, the usage and function of the two languages - Arabic and Turkish - was still distinguishable. Turkish was the preferred spoken language of the Mamluks; it carried with it familiarity and informality. ${ }^{37}$ It is true that sometimes colloquial Arabic was also used in purely Mamluk circles; some of these dialogues in vernacular Arabic - for example between Tankiz (d. 74I/r340) and Bahādur al-Ūshāqī (d. 744/1343) ${ }^{38}$ or between Qawșūn (d. 742/I 342) and Bashtāk (d. 742/I 34I) after al-Malik al-Nāșir's death ${ }^{39}$ - are preserved as important linguistic documents. In official functions, the same Bashtāk refused to use Arabic and rather employed an interpreter to have his Turkish translated. 40

Correspondingly, there were very few non-Mamluks in the fourteenth century who had mastered Turkish. Among these exceptions we must count the awläd al-nās - especially those

34 Flemming, 'Šerïf, 87-9. Yashbak was the addressee and possibly also the initiator of Abū Hāmid al-Qudsī's epistle on the blessing which the Mamluks brought to the land of Egypt. See also Brockelmann, GAL, II, 72.

35 Flemming, 'Literary Activities', 255. Ibn Ajā's Arabic Rị̣lat (tärïkb) alAmir Yasbbak al-Zäbiri, an interesting description of Yashbak's eastern campaigns (Cairo 1973-4), forms, at my suggestion, the backbone of Karin Klingbeil's Freiburg thesis on Mamluk relations with the Timurids and Turcomans.

36 Flemming, 'Aus den Nachtgesprächen', 22.

37 See the example given in Haarmann, Quellenstudien zur früben Mamlukenzeit (Freiburg 1969), 77 n. 2.

38 Al-Safadī, $x, 302,1.13$ and $303,1.4$.

39 Ibid., $x, 143,1$. I5-144, 1. 3 ; see also the numerous dialogues in colloquial Arabic in the tarjama of Baktamur al-Sāqī in idem, $x, 193-7$.

40 Ibid., X, I42, 1l. 6-7; cf. also Irwin, op, cit., I 26. 
with a Turkish mother - who retained easy access to the Mamluk quarters and, of course, the highly atypical case of the civilian Qāọī Ibrāhìm Jamāl al-Kufāt (d. 745/1 344) who rose, as a protégé of the amir Bashtāk just mentioned, from fruit-vendor to amir of a hundred, was named vizier, combined for the first time in Mamluk history the control of the Royal Fisc (nazar alkbāsss) and the Army Bureau (nazar al-jaysh), proudly wore the kallawta, and - to make the point - even went so far as to learn Turkish, the language of his new social environment. ${ }^{41}$ But Arabic held an unchallenged monopoly in the field of writing among the Mamluks - private soldiers, amirs, and sultans alike - before the last decade of the fourteenth century. One could nevertheless learn Turkish in this period if one really wanted to. In some madrasas founded in the fourteenth century by such grandees as Shaykhū and Sarghitmish, at least some professors were expected to be competent not only in Arabic but also in Turkish as well as Persian. ${ }^{42}$ The student body was supposed to be international (āfāqu is the term used in Barqūq's waqfiyya) and certainly open to newcomers - sometimes relatives of Mamluks arriving from the Dasht-i Qipchaq and the Caucasus to Cairo, the glittering centre of learning for the orthodox Islamic world.

Most Mamluks whose names are recorded in the chronicles and biographical dictionaries of the fourteenth century must have been able to communicate in Arabic. Those who had not mastered the language are explicitly mentioned. One wellknown example of the latter group is Sultan Zayn al-Din Kitbughā, who was of Oyrat-Mongol stock. ${ }^{43}$ Another wellknown name is Ulmās, al-Nāṣir's long-time chamberlain. He did

41 The Qādī Badr al-Dīn b. Jamāéa attended in 696/r 296 the crucial meeting of the leading amirs with Sultan Zayn al-Dīn Kitbughā in which the latter was forced to resign, and the conversation was held in Turkish; cf. Ibn al-Furāt, Tärïkh, viII (Beirut, 1939), 228. The Qādĩ al-Hasan b. Muhammad al-Ghawri al-Hanafi, who aroused public unrest in Cairo during the reigns of al-Manșūr Abū Bakr and al-Nāṣir Aḥmad in 742/I 341-2, addressed the sultan in Turkish; he later left Egypt and Syria and returned to his native Baghdad. Cf. Ibn Hajar, Ir, $127 \mathrm{f}$. For Qāḍī Ibrāhīm Jamāl al-Kufāt, see ibid., I, 82, and Ibn Taghrïbirdī, al-Nujüm al-zäbira fĩ mulüte Mișr wa '-Qäbira, x (Cairo, and edn., n.d.), I I I, l. ro.

42 I owe this important reference to Dr Leonor Fernandes of New York University, who has done extensive research on Mamluk endowment deeds.

43 Ibn [Aybak] al-Dawādārī, Durar al-tījän wa-ghurar tawāì̄kh al-azmān, ms. Damad Ibrahim Paşa, Istanbul, no. 91 3, year 693, fols 5-6; Haarmann, 'Alțun Hyān und Čingiz Hāan bei den ägyptischen Mamluken', Isl. s I (1974) S and $\mathrm{n} .2 \mathrm{r}$. 
not understand, let alone speak, one word of Arabic. ${ }^{44}$ This shortcoming did not affect his religious zeal, of which his splendid Friday mosque in Cairo bears witness.

Sultan Baybars al-Jāshnkīr, who mounted the throne for the short and eventful months between the second and the third reign of al-Nāṣir in 708-9/1309-10, had started to learn Arabic when he was imprisoned by the above-mentioned illiterate Kitbughā. Jails must have been favourite abodes of learning in Mamluk Egypt, if we remember Sultan Hasan's similar experience. ${ }^{45}$ Baybars al-Jāshnkīr seems to have achieved a high degree of proficiency in his Arabic, as he is praised not only for his munificence in pious building, but also for his library, which was stocked with precious books, including a lavishly executed copy of a Qur'ān written by Ibn Wahị̂d, a highly praised calligrapher of the time. ${ }^{46}$

Book-collecting was an expensive yet widespread hobby of cultured Mamluks. ${ }^{47}$ One may mention Baydarā (d. 693/r 293), al-Ashraf Khalīl's deputy, murderer, and short-term successor, who not only bought but also copied books in large numbers and owned valuable works such as Ibn al-Athīr's al-Kämil fï 'l-tārikeh in twelve volumes; ${ }^{48}$ other names are Shaykhū al-Sāqi al-Qāzāni (d. 752/135r), who was evidently a book addict and acquired precious works whatever their content and price, ${ }^{49}$ Baktamur al-Sāqi (d. 736/1335) in whose huge estate could be found several copies of al-Bukhārî̀s Sabīh, ${ }^{50}$ and Arghūn alNāșirī, viceregent of Egypt from 7II/I3 II to 724/1324, who displayed an 'immense care' ('ināya 'azima) for books and was

44 Ibn Hajar, II, 493. We hear of one Mamluk amir serving as dawädār who had difficulty in calculating properly; see the vita of Balabān al-Dawādār (d. 680/I 28I) in al-Safadi, $\mathrm{X}, 282,11.5-\mathrm{I} 3$.

45 Other Mamluk prison inmates developed refined manual skills; take the exemple of Lājīn al-Manșūiñ al-Zīrabāj ('the almond pie'), d. 73 1/1330, who produced exquisite wool whilst in detention (Ibn Hajar, IIr, 357-8).

46 Al-Șafadī, x, 350; Ibn Hajar, II, 40.

47 E.g. Aybak al-Muhyawī (al-Șafadī, Ix, 48r); Baydamur al-Badrī, d. $748 / 1347$, for a time $n \vec{a} \mathbf{i} b$ of Tripolis and Aleppo (Ibn Hajar, Ir, 46); Aybak al-Turkī, d. 776/r 374-s (ibid., I, 450); Āqsunqur al-Nāșirī, d. 748/1 347 (ibid., I, 422); Baktāsh al-Mankuwarasī, d. 757/1356 (ibid., II, Is). On book collecting as a typically Mamluk passion, see Schimmel's short remarks in her 'Kalif und Kadi', 4 and n. 3.

48 Al-Șafadi, $x, 360-2$.

49 Ibid., XVI, $210-1 \mathrm{r}$.

50 Ibid., x, 194, 11. 16-18. For Baktamur's life, see ibid., 193-7; Ibn Hajar, II, I9-2I. 
regarded, on these grounds, as highly atypical for his race. ${ }^{51}$ Țaybughā al-Dawādār al-Ānūkī (d. 752/I35I), the fearfully strict and wily supervisor of the chancery during Sultan Hasan's first reign, did not have (or want to spend) the money to buy books; he borrowed them in large numbers. ${ }^{52}$

The amir Qibjaq al-Manșūrī (d. 710/1 310), for a short time Läjīn's Syrian viceroy, came from a family of eminent Mongol scribes. He spoke and wrote Mongolian fluently, yet he excelled also in his mastery of Arabic. ${ }^{53}$ The amīr Arghūn al- Alā'̄, regent (akbar al-umarä wa-mudabbir al-mamälìk ${ }^{54}$ ) under alNāsir's son Ismāêil, not only built a kbānaqāh and supervised Qalāwūn's famous hospital, but also wrote a scholarly work in Arabic. 55 Also, calligraphic skills are consistently recorded; as we have heard, the young Mamluk cadets were taught the art of writing in the first phase of their education. ${ }^{56}$ Not surprisingly,

51 Al-Ṣafadī, viII, ed. M.Y. Najm (Wiesbaden I97I), 358-60; Ibn Hajar, I, 374; see also Irwin's remark, The Middle East in the Middle Ages, ro7.

52 Ibn Hajar, II, 33 I-2. The names given are only a selection. One may add e.g. Qijlīs al-Nāṣirī al-Silāḥdār (d. 731/r 330), an expert on time-keeping (miqät) and of legendary physical strength; the people loved him for his kind and unassuming manners. He, too, had a weakness for rare books; Ibn Hajar, III, 328.

53 D. P. Little, 'Notes on Aitamiš, a Mongol Mamluk', in Ulrich Haarmann and Peter Bachmann (eds) Der islamische Orient qwischen Mittelalter und Neuzeit. Festschrift für Hans Robert Roemer (Wiesbaden 1979), 387-401, at 392. Little's reference is to al-Ṣafadī, xxrv, ms. Ahmet III, Istanbul, no. 2929, fol. $8 \mathrm{Ib}$; an edition of this volume is being prepared by Adnan Bakhit and Mustafa Hiyari of Jordan University, Amman. Ibn Hajar, III, $325-7$, in his disproportionately long biography of Qibjaq, says nothing about his philological and literary interests.

54 On this office, see P.M. Holt, 'The Structure of Government in the Mamluk Sultanate', in The Eastern Mediterranean Lands in the Period of the Crusades, ed. Holt (Warminster 1977), 54f.

55 Ibn Hajar, I, 376.

56 A few examples: the amir Shaykhū al-Sāqī, mentioned above (n. 49); the amir Tashbughā al-Dawādār al-Nāșirī (d. 752/1351), dawādār kabìr during Sultan Hasan's first rule (al-Șafadī, xvI, 535-6; Ibn Hajar, II, 319); Țayțaq al-Ahmadī (d. $76_{3} / \mathrm{r}_{3} 62$ ), dawädār in Aleppo and governor of al-Raḥba, 'an educated man with a beautiful handwriting' (ibid., II, 32I); TTaybughā al-Dawādār al-Ānūkī (see above, n. 52) 'with his elegant script'. Also Sanjar al-Shujāēī, al-Ashraf Khalīl's vizier (d. 693/1 294) had acquired orthographic/ calligraphic skills (al-Șafadī, xv, ed. Bernd Radtke (Wiesbaden 1979), 487, sf.). Baydamur al-Badrī (d. 748/1348) 'undertook the copying of the Qur'ān with his own hand' (al-Ṣafadī, $x, 363$, 1. I5; Ibn Hajar, Ir, 46). A beautiful script and lively philological interests went together in most of these cases. 
the office of dawāatar attracted Mamluks with such talents in respectable numbers.

Several Mamluks are described as authors of good verse and as literary entertainers. ${ }^{57}$ Aybak al-Muhyawī, a praised adīb, deserves to be singled out because of his broad erudition. ${ }^{88}$ The enormous prestige of Arabic in Mamluk circles is best documented in the vita of the amīr Bāshqird (d. 702/r 302). He was so eager to master it that he refrained from the usage of his native Turkish for twenty consecutive years. This strange behaviour won him strong compliments from Ibn Hajar, his biographer, who credits him with a rare natural gift of writing verses in Arabic. 59

Whenever the biographers single out Mamluks of the fourteenth century for their culture, we can be sure that their command of Arabic was impressive. Qushtamur al-Manșūiñ, governor of Aleppo, who died fighting seditious Bedouins in the Syrian Desert in 775/1 374, had mastered the difficult grammatical rules of classical Arabic. ${ }^{60}$ Perhaps the best known example is the historian Baybars al-Manșūrī (d. 725/1325), 'a noble representative of his race', to use Ibn Hajar's words. ${ }^{61}$ Arghūn al-Dawādār (d. 731/1330-r), a religious zealot who chased out of office all non-Muslims under his control, was another favourite of contemporary critics; though he was a Turk, his eloquence (sc. in Arabic) was remarkable. 62 The amirs Baktamur al-Hājib 63 (d. after 719/1319) and Alțunbughā alHajijib, wāli of Aleppo (d. 742/1342), are given the rather modern-sounding epithet muthaqqaf, 'polished', cultured. Alțunbughā al-Ḥajijib was versed in Muslim religious law, besides his

57 E.g. Iyās b. 'Abdallāh al-Dhahabī, born in 687/ 1 288, Ibn Hajar, I, 449; Aydamur b. 'Abdallāh al-Sinā̄̄î, otherwise al-Sinān̄ al-Kurjī̄, 'the Georgian', d. 707/1 307, al-Șafadî, x, I5; Ibn Hajar, I, 457 (al-Șafadi gives numerous lines of his poetry, pp. 15-17); Läjīn al-Dhababī, born in 659/1261, Ibn Hajar, III, 357 . See also the addendum on P. II 4 .

58 Al-Șafadī, Ix, $48 \mathrm{I}$; see also above, n. 47.

$59 \mathrm{II}, 3$.

60 Ibid., IIr, 334, 1. To; he is also credited with a beautiful script. Ibn Hajar's report about Qushtamur's death is taken from al- 'Uthmānī's lost(?) - Tärīkb Șafad (ibid., l. I).

61 Ir, 43. Al-Ṣafadî's tarjama, $x, 352$, is surprisingly short and uniformative.

62 Dhahabī, in Ibn Hajar, I, 374; al-Ṣafadi, virr, 358-60.

63 Ibid., X, 190, 6; Ibn Hajar, II, 17-18; neither author gives his death date. 
mastery in the genuine Mamluk crafts of furüsiyya, warfare (jaysh), and siyāsa. ${ }^{64}$

Khalī b. Aybak al-Șafadī praises even more profoundly Alțunbughā al-Jāwulī (d. 744/I3.43), 'a rare member of his people'. ${ }^{65} \mathrm{Al}$-Jāwulī, originally an amir's dawādār in Ghazza, held an iqta $a^{-}$as a member of the balqa of Damascus and ended his public career as superintendent (shädd) of Qalāwūn's complex in the heart of Cairo. He combined prowess in the military arts with wide learning in the fields of Shāfi $\bar{i}$ jurisprudence and grammar ${ }^{66}$ (a discipline mastered also by a few other Mamluks quite impressively ${ }^{67}$ ), with excellence in chess and with a special talent for writing poetry in Arabic. He was business-minded enough to have himself paid one dinar for each verse of a qasida he wrote at the order of his Mamluk ustädh. Al-Safadī knew this man in person and quotes several of his poems. Interestingly enough, the only fault he finds with him is his religious outlook; al-Jāwuli temporarily leaned towards the rigorist teachings of Ibn Taymiyya. ${ }^{68}$ Evidently an élite also among the Mamluks and, as we shall see later, the awläd al-nās were susceptible to the new fundamentalism. In a poem al-Jāwuli succinctly characterizes himself as a prototype of this small Mamluk intelligentsia, who had mastered the cultural norms of their environment and thus gained the respect of the local 'ulam $\vec{a}$ ' critics, by labelling himself as musta' rab al-lafz $l i$ 'l-aträk nisbatan, as 'a man who has become an Arab in his language

64 Al-Ṣafadī, Ix, 36I-3; Ibn Ḥajar, I, 436.

65 IX, 366-9.

66 See ibid., 368 , 1l. 2-3, for a poem in which he alludes to the nubät.

67 E.g. Baktūt al-Muhammadī (d. after 700/1300), a sometime student of the philologist Athīr al-Din Abū Hayyān and a mediocre poet; cf. al-Ṣafadī, x, 20I; Ibn Hajar, Ir, 21-12. The Syrian Taybars al-Jundī, i.e. a Mamluk private soldier, who died in al-Sălihịyya in $749 / \times 348-9$, was, besides his competence in figh and, again, his second-rate (mutawassit) poetry, a star grammarian in his class; he versified, in a poem of 900 lines, the Alfyya and Ibn al-Hājib's Muqaddima; cf. ibid., II, 330.

68 The famous Qarāsunqur al-Jūkandār al-Manșūīi (d. 728/I328) also admired Ibn Taymiyya; cf. ibid., IIr, 331-2. Quṭlūbak al-Manșūrỉs (d. $716 /$ I $316-17$ ) relationship to the great theologian was less harmonious; see ibid., III, $337,1.3-338,1.3$. Quṭlübak resented Ibn Taymiyya's request for legal assistance: 'if an amir comes to the gate of a religious man (i.e. seeking help or advice), what a compliment to both sides; but if a faqir comes to an amir, what a shame for both ...'; Ibn Taymiyya, referring to the example of Mūsā soliciting Fir'awn's imān every day anew, tried to thwart Quṭlūbak's resistence, whether successfully or not, we are not told; see ibid., 338, 1l. I-3. 
though being of Turkish descent'. ${ }^{69}$ That Ibn Hajar charges this same al-Jāwuli with an addiction to alchemy, ${ }^{70}$ reminds us of his Mamluk background; magic, alchemy, treasure-hunting, and various divinatory practices ${ }^{71}$ were particularly popular in Mamluk circles as an obvious vestige of their shamanistic past. ${ }^{72}$ Aytamish, an expert in Mongol language, writing and history, though not in Arabic, was also a specialist in the arcane science of incantations and charms. ${ }^{73}$

Many fourteenth-century Mamluks became religious scholars, usually concentrating on badith and figh. In this respect they do not differ from non-Mamluk 'ulamă $\vec{a}$, nor from the awläd al-nās who went into scholarship.

Sanjar al-Dawādārī (d. 699/I 299-I300), one of the most original personalities of early Mamluk history, spent - according to the contemporary reports by al-Dhahabī ${ }^{74}$ and al-Ṣafadi ${ }^{75}$ more than fifty years of his life studying the science of tradition in centres as far afield as Anțākiya, Ba albakk, Jerusalem, Jidda, al-Fayyūm, and Qūṣ; had important mubaddithün and historians such as al-Birzāli and al-Mizzì as his pupils; and was famed for his flourishing majlis frequented by 'scholars, poets, and dignitaries alike'.76 'Hardly any Turk equalled him in

69 Ibid., II, $367,1.7$.

70 Ibid., I, 435 .

71 On their penchant for unorthodox drugs and popular medicine, see the vita of Bahādur al-Timurtāshī in al-Șafadī, x, 299, ll. I4ff.; significantly the healer in this case came from the Maghrib, the proverbial land of magic and sorcery.

72 Baktūt al-Qaramānī (d. $749 /$ I 348 of the plague) was addicted to the craft of the matălib, searching out hidden treasures, and to alchemy; Ibn Hajar, II, 23. The wajfidī amir al-Husayn al-Khilāți al-Lāzawardī, who gained Barquaq's attention, was famed for his supranatural qualities; ibid., II, I60. One may add in this context the two names of Âqqüsh al-Qibjāqī who claimed to be a prophet and was executed in 665/1 266-7 (al-Șafadi, Ix, 322), and of the impostor Jülajīn, a specialist in malähim, prophesies of the future, who met his end in 715/1315-16; Ibn Hajar, II, 80. Aydamur al-Sinānī alKurji (see above, n. 57) was renowned for his mastery in the interpretation of dreams. Aqqūsh al-Afram al-Jarkasī (ibid., I, 424-6) was a celebrated astrologer who remained addicted to the Mamluk arts in spite of his close ties to local 'ulamä' such as Ibn al-Wakil; he died after $720 / 1320$.

73 Ibid., I, 453 . One may mention, in this context, also the 'ornithologist' Mughultāyy al-Baysarī, one of the amirs of Damascus (d. 707/1307); ibid., v, x24.

74 Kitāb al-"Ibar, ed. Ș. al-Munajjid (Kuwait 1966), v, 399.

$75 \mathrm{xv}, 479-82$, at 479,1 . 8. Since he died in 699 , Ibn Hajar did not include him in his Durar.

76 Al-Ṣafadī, xv, 479. 1. I9. 
excellence', one said of him with reverence. ${ }^{77} \mathrm{He}$ left decent poetry, of which al-Ṣafadi gives examples, ${ }^{78}$ and wrote numerous works in his own beautiful handwriting. Like many other military men of his time he clothed himself $b i$ 'l-faqiri, as a Sufi, and sought again and again the seclusion and peace of the Holy Places in Arabia, far away from the noise and turmoil of the Mamluk capital. He made the pilgrimage six times (once even on a camel's back, despite his high social standing) and was the first to bring the kiswa from Egypt to Mecca after Hülägü's conquest of Baghdad. He seems to have been one of Baybars' favourites; in 678/1 280 he sided with the rebellious Sunqur alAshqar, yet managed to regain the respect of the victorious Qalāwūn, and was later even promoted to an amirate of a hundred. Làjīn, with his keen interest in scholarship, entrusted to Sanjar the superintendence of the mosque of Ibn Tülūn in Cairo, which had by then lost much of its former prestige; Sanjar replenished its endowment and appointed new professors for law, badith, and medicine. When campaigning, Sanjar had some companion read out to him prophetic traditions about jibäd. He died peacefully, quite appropriately, after a successful raid on Cilician Armenia in the beautiful surroundings of the Crac des Chevaliers (Hiṣn al-Akrād) in the Syrian coastal range.

Numerous other Mamluks shared Sanjar's penchant for the legal and religious sciences, and we find them in the highest and lowest military ranks. Thus neither of the jundīs Aqqūsh al-Iftikhārī al-Shiblī (d. 699/I 299-1300), a teacher of the religious sciences with a praiseworthy handwriting, ${ }^{79}$ and Sanjar al-Iftikhārī (d. 74I/I 340), a popular traditionist in Cairo's Husayniyya quarter, ${ }^{80}$ ever advanced to an imra. Ghulbuk alTurkī al-Z̄āhirī al-Khaznadārī, who taught Ibn Hajar's teachers badith (d. 74I/I 34I), must have been of equally modest social status. ${ }^{81}$

On the other hand, we find Sanjar al-Jāwulī (d. 745/1345), governor of al-Shawbak and holder of the highest military rank. He was a productive mubaddith and Shāfi ī jurist. ${ }^{82}$ Șarghitmish, the strong man before Sultan Hasan's second rule (d. 759/1358),

77 Ibid., Xv, 480, 1. 9.

78 Ibid., Xv, 481, 1. 10-48 2, 1. 9.

79 Ibid., Ix, 325.

80 Ibn Hajar, II, 270.

81 Ibid., III, 298, no. 3147 .

82 Al-Ṣafadī, xv, 482-4; Ibn Hajar, II, 266-8. 
on the other hand, as well as Hasan's former khasssaki and murderer Yalbughā al-Nāṣirī (d. 768/1366)83 staunchly and, in Yalbughā's case, quite aggressively supported the Hanafí, Turkish, cause against the Shafie i madhbab of the local population of Egypt. Șarghitmish's declared favourites were, quite consistently with these legal policies, the ajam, the non-Arabs. Yet the same Sarghitmish had studied not only (Hanafi) law, but also Arabic; he helped the 'ulamä of his denomination and was a munificent patron of religious architecture. ${ }^{84}$ Tankiz, alNāṣir's plenipotentiary governor in Damascus, also never seems to have lost his keen and active interest in the science of tradition. ${ }^{85}$ In the thirteenth century we hear of Baybars al'Adīmi (d. 713/1313) who until beyond his biblical age span remained illiterate and never shed his Turkish accent, yet was a prolific and popular teacher of badith. 86 And there was Bilik alKhaznadār (d. 676/r 277), who stunned his contemporaries with his facility in speaking foreign languages and writing and composing poetry, and who was also an enthusiastic student of history and of badith. He again was a generous patron of the teaching of Shāfi ${ }^{e} \overline{1}$ jurisprudence at al-Azhar. ${ }^{87}$

Balabān b. Shaklān, amir and wāli of the province of al-Sharqiyya, was not only a valiant fighter against the unruly Bedouins of the area - this earned him the sobriquet al-Ghülmishi, 'the ghoul is gone' - but also a respected mubaddith. ${ }^{88} \mathrm{Al}$ Șafadī himself received one legal ijāza from the Mamluk Husām al-Dīn Turuntāy al-Zaynī (d. 731/1331), who had been the dawāāàr of Sultan Kitbughā. ${ }^{89}$

83 Ibid., v, 2 I 4.

84 Ibid., II, 305-6; see also Irwin, op. cit., 142.

85 Al-Șafadī, x, 420-35, exp. 420.

86 Ibid., $\mathrm{X}, 35 \mathrm{I}$.

87 Ibid., $x, 365-7$.

88 Ibn Hajar, II, 24f. Only a few other names of such scholars shall be given here: Balabān b. 'Abdallāh al-Su'ūidi, d. 736/1335, who was for a short term in charge of the zäwiya of Shaykh Abu 'l-Su'üd (ibid., II, $25 \mathrm{f}$.); Bahādur b. 'Abdallāh al-Badrī, d. 769/1 368 (ibid., II, 29); Baybars al-Qaymarī, d. 704/1305, an amîr silähdär (ibid., II, 42); the famous Baybars al-Mansuūī (see above, n. 6I); Bīlìk b. 'Abdallāh al-Khațībĩ, d. 73I/133I, who studied the works of Ahmad b. Hanbal (ibid., II, 48); Kaykaldī b. 'Abdallāh al-Dimashqī, d. 742/1 342, a freedman (ibid., IIr, 356); Làjīn al-Badrī, d. 739/1339, also a freedman (ibid., III, 357).

89 Al-Ṣafadī, XVI, 432, 11. I-3; Ibn Hajar, II, 317. He does not seem to be identical with Turunțāy, one of Kitbughā's Mamluks, who was also fond of badith and scholarship, yet died in 728/1328; cf. ibid., II, 329, no. 2013. 
Most of these Mamluk 'ulam $\tilde{a}^{3}$ had strong leanings towards Sufism, another common feature of contemporary scholarship. Wara' and 'ilm are also frequently used epithets of Mamluks who made themselves a brilliant career in the state and in the army. The Anatolian Älmalik al-Hājj, whom Sultan Baybars I had captured in his campaign to Elbistān in 676/1277 and who ended his days ignominiously in the state prison in Alexandria in $746 / 1345$, is even uniquely denoted as an amir-shaykh. He served for a short time as viceregent in Damascus. He was a patron of scholars and Sufis and received a mashyakba from renowned jurists of his time. He used to dispense justice from the window of the governor's palace. He was famed and feared for his unimpeachable morality and his perseverance in the prosecution of crime and vice. 90

Another patron and adept of legal matters was Uljāy (d. 732/ I332), like so many other Mamluks a champion of books and of calligraphy. He cherished the companionship of the great jurists of his day. Uljāy's favoured house-guest was the Shäfi ${ }^{e}$ scholar Taqī al-Din al-Subkī (d. 756/1355). ${ }^{91}$ Subkī wrote some very topical treatises, for example on the right of the donor of a waqf to reserve the administration of his endowment to himself and his progeny. ${ }^{92} \mathrm{He}$ spent most nights on the premises of Uljāy's hospitable palace on the Cairo citadel. It is worth mentioning that Uljāy himself held the post of dawyadar, secretary. He thus held the office that was ideal for the establishment and cultivation of contacts between the military government and local 'ulamä.93

What do we know about an original and genuine non-Arabic Mamluk culture? Only a few Mamluks contrived to keep their native traditions alive in the new environment that was hostile to the Turco-Mongol heritage and was ruled exclusively by the statutes of Islam. We shall see that this task of describing the fascinating world of the far distant West and Central Asian Mamluk homeland and of its lore fell largely upon awläd al-nās and not upon Mamluks. Those Mamluks who made an effort to be accepted by Muslim-Arab critics as writers or scholars seem to have been careful not to destroy their chances of success by reminding their audience too much of their pagan provenance.

90 Al-Ṣafadī, Ix, $372 \mathrm{f}$; I Ibn Hajar, I, $439 \mathrm{f}$.

91 Brockelmann, GAL, II, 87.

92 Loc. cit., no. 9: al-Qawl al-müंib fi 'l-qadä' al-müjib.

93 On Uljāy, see al-Ṣafadī, rx, 353 f.; Ibn Ḥajar, I, 433. 
In this respect, the amir Quṭlūbak al-Manșūrī al-Kabīr (d. 716/1316-17), the imperious governor of Safad in the early fourteenth century, appears to have been a striking exception. He knew Arabic grammar, law, tradition, and early Islamic history, he had the handwriting of a strong personality, he himself wrote anecdotes (nawädir) and rather dull poetry (shir bärid), yet at the same time he made a point of appearing in Mongol garments. ${ }^{94}$

The awläd al-nās, on the other hand, were Muslims by birth and were native Syrians or Egyptians. They spoke and wrote Arabic as their first language. Without the fear of being ostracized as infidel barbarians, they were free to use these exotic materials without restraint, in order to give additional glamour and excitement to their writing. Such Mongol-Turkish ' $a j a{ }^{3} i b$ could enhance their popularity among the readers on whose interest and good-will many an ibn al-näs depended. Yet, to our regret, hardly any of them used this chance, at least not in the period under discussion.

So there are few names of Mamluks on record who acquired fame as experts on the culture, history, and speech of the Turks and Mongols. The historian Baybars al-Manșūrī, an amir of unusual erudition, gives special attention to events that took place in the territories of the Golden Horde and the İlkhāns. The amir Qibjaq - like Baybars al-Manșūiñ, a Mamluk who accomplished a brilliant military career - was an expert on Mongolian, as we have seen, and he seems to have patronized other Mamluks who spoke and wrote this language. ${ }^{95} \mathrm{Al}-$ 'Umari and al-Qalqashandī give the names of those four Mamluks who were charged with the duty of writing official letters in Mongolian in the time of al-Nāșir Muhammad. ${ }^{96}$ One of these four was the famous Aytamish al-Muhammadi (d. 737 / 1337), one of Qibjaq's protégés. ${ }^{97}$ Aytamish, who rose to the rank of a provincial governor, had an excellent command of Mongolian: 'his mastery of the Mongol language ... was so

94 Ibid., III, 337-8; see also above, n. 68.

95 Little, 'Notes on Aitamiš', 392, quoting from al-Yūsufī, Nuzhat al-nāzìir "fi sïrat al-Malik al-Nāssir, ms. Ayasofya, Istanbul, no. 3434, fol. I $29 \mathrm{~b}$.

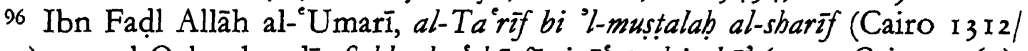
1894), 47; al-Qalqashandī, Subb al-a 'shä fi sināa at al-inshä’ (repr. Cairo 1963), vII, 294. The four names are Aytamish, Țāyirbughā, R-gh-d-l-q al-Tarjumān and Qawșūn al-Sāqī. See also Little's comments, loc. cit.

97 See n. 95. 
perfect that he had amongst the Mongols the status which a grammarian has among the common people'. ${ }^{98}$ The historian alYūsufi, a close friend of Aytamish, praises his beautiful Uyghur handwriting. ${ }^{99}$ It is difficult to judge what exactly al-Safadi means when he extols Aytamish because he knew the 'houses, genealogies, and origins of the Mongols and had memorized their histories and deeds'; ${ }^{100}$ he certainly regarded him as an exception among his fellow-Mamluks. After the researches of David Ayalon and Donald Little, we now know that Aytamish most probably did not implement the yāsa of Chingiz Khān, whatever this term exactly denotes in this context, among the khäșsakikiyya bodyguard, as al-Șafadī claims. ${ }^{101}$ Aytamish's historical achievement lies in his three journeys to the court of the İlkhān Abū Sa'ìd; together with the merchant-envoy al-Majd alSallāmi he seems to have paved the way for the truce that was concluded between al-Nāșir and the İlkhān in 723/1 323.102

For our purposes, Aytamish's akh, ${ }^{103}$ the popular Aruqtāy alHāji (d. 750/ $\mathrm{r} 49$ ), is yet more important. ${ }^{104}$ The historian alSafadi knew both of them well from the days when they held office in his native Șafad. As a soldier, Aruqțāy was even more successful than his companion Aytamish. Under al-Nāṣir's sons he rose to the rank of viceroy in Damascus. Aruqtāy was the ustādh of the Mamluk poet and adīb Altunbughā al-Jāwulī105 who has been mentioned previously. Though al-Ṣafadi certainly exaggerates when he names him, together with Aytamish, as

98 Ibn Hajar, I, 453. D. Ayalon, 'The Great Yāsa of Chingiz Khān. A ReExamination. C 2', SI 38 (1973) I 36 , translates al-nabwi as 'linguist'.

99 Nuzbat al-nãzir, fol. 129b (see n. 95).

100 A yān al-aṣr wa-a wān al-așr, ms. Atıf Efendi, Istanbul, no. I 809, fol. rosa (Little's reference and translation). Cf. also al-Şafadỉs version in his Wāfí, Ix, 440, ll. 7 ff.: wa-kāna ya rifu sīrat Jinkiz Kbān wa-yuțäli ubä wayurāji uhā wa-ya rifu buyūt al-Mugbul wa-usūlabum wa-yastabdiru tawārīkhabum wawaqa $\vec{a} i$ abum. This passage has also been studied by Ayalon, op. cit., 135 . Ibn Hajar, II, 453, slightly paraphrases al-Șafadỉ's text.

$101 \mathrm{IX}, 440$, 11. 6-7.

102 Little, 'Notes on Aitamiš', passim.

103 On the meaning of the term $a k b$ in a Mamluk context, see B. Schäfer, Beiträge zur mamlukischen Historiograpbie nach dem Tode al-Malik an-Nāsirs. Mit

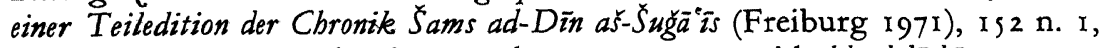
and 160 . She proves that it cannot be synonymous with khushdasshi.

104 Al-Șafadī, virr, 36r-3. On the reading Aruqțāy (instead of Ariqțāy), cf. al-Șafadī, $x, 362$, l. I 2 .

105 Ibid., Ix, 366, 1. 10. 
active in the administration of the yasa among the Mamluks, ${ }^{106}$ we should accept his praise of Aruqtāy's 'eloquence in the Qipchaq [and] Turkish language[s]'107 and of his personal culture. Aruqtây's accent when he spoke Arabic remained heavy his whole life long, ${ }^{108}$ a fault which no non-Mamluk critic was likely to neglect.

\section{III}

The term awläd al-nās, 'children of the [Mamluk] élite', denotes the offspring of Mamluk amirs. They stood between the Mamluks and the native population. Their most respected and privileged representatives were the sayyidīs/asyäd awläd al-mulük, the sons of living or deceased sultans. According to the unwritten Mamluk constitution, these awläd al-nās were deprived of full Mamluk privileges and career opportunities because they were born free Muslims inside the där al-isläm and were thus automatically evicted from the ruling one-generation military aristocracy, to use David Ayalon's ingenious definition of the Mamluk ruling class. They could not normally attain the highest military ranks and offices in the state, though they enjoyed a prestigious standing and formed a special unit of the balqa, the non-Mamluk cavalry, a regiment that goes back to Saladin's bodyguard. Only few of them bore Turkish names. ${ }^{109}$ The designation awlād al-nās remained valid down to Mamluk

106 Ibid., viIr, 361, 11. 5-6. A glimpse of the autonomous legal world of the Mamluks, so it seems, is also afforded in the biography of Maliktamur alNāṣirī al-Hijāzī, who was killed in 748/1 347; Ibn Ḥajar, v, r28, 1l. 7-ı

107 Al-Ṣafadī, virr, 36r, ll. 5-6.

108 Ibn Hajar, I, 376 (ma'a 'ujma fĩ lisānibì).

109 E.g. the amir Qurmishi who rose to the rank of amir tablkbāna and was awarded the office of chamberlain in Damascus, dying in $747 / 1346$; see

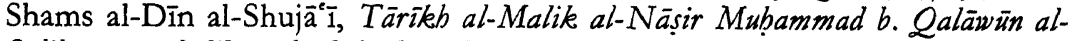
Sälibị wa-awladibì, ed. Schäfer (Cairo 1978), 80; Ibn Hajar, III, $332 \mathrm{f}$. His father Aqțuwān al-Kamālī (d. 734/1333) was ḅäjib in Șafad during the governorate of Aruqțāy al-Hājj; cf. al-Ṣafadī, Ix, $320 \mathrm{ff}$; I Ibn Hajar, I, $422 \mathrm{f}$. Other examples are Arghūn b. Qīrān al-Sallärī, the naqüb al-jaysh under Sultan Hasan (d. 772/r 370-r) (cf. ibid., I, 373); Asanbughā b. Baktamur alBūbakrī (d. 777/1 375-6), who was, if only for a short time, governor in Aleppo and regent in Cairo, patronizing building and religious activities (ibid., I, 4I 2); al-Amīr Sayf al-Dīn Bahādur b. Jiriktamur (al-Șafadī, x, 250 , l. 19, in the vita of Abū Bakr b. Muhammad b. Qalāwūn); Bahādur b. Sāṭilmish al-Balāțunusī (d. after 770/r 368; Ibn Hajar, II, 29). 
scions in the fourth generation, ${ }^{110}$ an indication of their continuing ties to the Mamluk hierarchy.

Relatively little is known about the awläd al-nās. ${ }^{111}$ Even the Arabic term lacks full clarity. We do not know when exactly in the fourteenth century the phrase awläd al-nās began to be used to denote descendants of amirs. We have no detailed information about the impact of the decay of the balqa on their social and economic standing after al-Malik al-Nāșir's redistribution of $i q t a \bar{s}$ s (al-rawk al-Nāssir $\overrightarrow{\text { ) }}$ in the beginning of the fourteenth century. To what degree did they form at all a clearly definable separate group, both in their own eyes and in the eyes of contemporary society? In the mid-fourteenth century, under the rule of al-Nāṣir's cultured son Hasan, who was himself a sayyidi in the third generation and very reserved towards the genuine Mamluks (he even gave up his Turkish name, Qumāri $1^{112}$ ), the awläd al-nās briefly enjoyed a privileged position in the state. To the dismay of full-blooded Mamluks, they became favourite candidates for the highest offices in the state. This short-lived upsurge under Hasan of the awläd al-nās, and also of other nonMamluk groups such as eunuchs and slave girls, clearly reflects the political and institutional chaos in the forties of the fourteenth century. ${ }^{113}$

For our concern, Mamluk intellectual and cultural history, the awläd al-nās are important because they present themselves as the given middlemen between the powerful Qipchaq or

110 The chronicler Ibn Iyās is an example; see M. Mostafa, 'Beiträge zur Geschichte Ägyptens zur Zeit der türkischen Eroberung', ZDMG 89 (1935) 217.

111 For the time being, we still rely on the few articles written on them. See the cursory comments in Schimmel's Studien, 2-3; Ayalon in his 'Studies on the Structure of the Mamluk army - II', in BSOAS Is (I953) 456-8; Haarmann, 'The Sons of Mamluks as Fief-holders in Late Medieval Egypt', in Tarif Khalidi (ed.), Land Tenure and Social Transformation in the Middle East (Beirut, American University 1984), 141-68. I have begun, during my stay at the Institute for Advanced Study at Princeton, a comprehensive study of their military, economic, and cultural standing during the sultanate from I 250 to I 5 17; here I only offer initial and selected results from the sphere of culture, restricted to the Bahrī period.

112 This name was quite frequent; cf. the four Qumārīs mentioned in Ibn Hajar, III, 34I (nos. 3276-9). On the question of how and by whom Mamluk names (and regnal titles) were conferred, see the remark in al-Ṣafadi, $x, 144$, 1. s, on al-Manșūr Abū Bakr, al-Nāșir's immediate successor.

113 Ibn Taghrïbirdī, al-Nujūm al-zäbira, x, 309 and n. I. See also Ayalon, 'The Eunuchs', 282-95. 
Circassian military élite garrisoned in the Cairo citadel, on the one hand, and the local scholarly establishment, the Arabicspeaking 'ulama $\vec{a}$ ' with all their religious dignity and intellectual burden, on the other. ${ }^{114}$ The awläd al-nâs are the only group among those who stood between the Mamluks and the local populace to have full access to the Mamluk world which was so alien to the local observers. This intermediary position is supported by the fact that several awläd al-nâs had their own coat-of-arms, in principle a prerogative of genuine Mamluks. ${ }^{115}$ Their heraldic emblem was the pen-box, the blazon of the dawädär, the Mamluk secretary of state who had often undergone some scholarly training. ${ }^{116}$ The pen-box seems to underscore their close ties also with the local non-Mamluk religious and scholarly bureaucracy. Many awläd al-nās served in the Mamluk dĩwän. Significantly enough, they were strongly represented in those offices, for example the vizierate, that were not clearly defined as either military or civil.117

Awläd al-nās made their first acquaintance with the world of learning in the houses of their fathers, where local teachers instructed them in the religious sciences. Many awläd al-nās of noble Mamluk descent found or strengthened their ties to scholarship when they were installed as administrators of awqäf, pious endowments, which their fathers had established, ${ }^{118}$ not

114 Lapidus, Muslim Cities, II6, rather seems to underestimate their significance in the cultural and social life of the period.

115 Meinecke, 'Zur mamlukischen Heraldik', Mitteilungen des Deutschen Arcbäologischen Instituts Abteilung Kairo 28 (1972) 28 I-5.

116 Before 1350 the promotion of a dawadār to a rank higher than amir tablehäna was truly exceptional (cf. al-Ṣafadi, xvI, 387, 1. I 2 in the vita of TTàjār); these career limitations, too, connect the dawaadariyya with the awläd al-nās. Among the dawādäriyya who were well educated one may mention, e.g., Turuntāay al-Zaynī (ibid., xvr, 432), Tashbughā al-Nāṣirī (ibid., xvi, 435-6; Ibn Hajar, II, 319) and Tayțaq al-Aḥmadī (d. 763/1362; see above, n. 56$)$.

117 Ibrāhìm b. Qarawina, d. 771/1369-70, twice vizier (Ibn Hajar, I, 54) and Ahmad b. Baktūt, d. $774 / 1372-3$, superintendent of the treasury and chief secretary in Tripoli and Aleppo (ibid., I, r23), are two examples.

118 E.g. Abū Bakr b. Aybak al-Ḥusāmī, d. 756/r355 (ibid., I, 47r); Khalī b. 'Alī b. Sallār, d. 770/I 368-9, an amir and nāzirir al-awqāf (ibid., Ir, I79); Aḥmad b. Mughulțāy al-Shamsī al-Manșūrī, d. 764/1362-3 (ibid., I, 339); Muhammad b. Iyāz, d. 684/ I28 s (al-Ṣafadī, II, 232f.). Al-Ṣafadī was himself in Cairo when the powerful amir al-Afram al-Kabir. (d. 695/ $295-6$ ), much to the dismay of the dimän officials, entrusted his own aw qâf to his ill-reputed sons (Ix, 478). 
least in an effort to secure for themselves and for their children at least part of the perishable wealth which they had accumulated during their tenure of lucrative public offices. ${ }^{119}$ Iqtā ${ }^{-}$s could only rarely be bequeathed to the next generation. ${ }^{120}$ Some of them used their position to develop exceptional business skills. ${ }^{121}$

We find awläd al-nās prominent in various fields of learning. Some of the great historians of the Mamluk period were of Mamluk extraction, notably Khalīl b. Aybak al-Șafadī and Ibn Taghribirdī in the first generation, Ibn al-Dawādārī in the second, and Ibn Iyās in the third. Awläd al-nās were active across the full spectrum of the religious sciences. Idris $b$. Baydakin b. 'Abdallāh al-Turkumānī al-Hanafī of the fourteenth century wrote his exciting epistle against unlawful innovation, K. al-Luma' fi 'l-hawädith wa ' -bida.'.122 Others had Sufi inclinations. Ibrāhim b. Làjīn, who died of the plague in 749/1 348, accomplished an academic career in the fields of $u s \bar{u} l$ al-figh, logic and grammar, and then rejected the prestigious post of qä $\bar{i} \bar{z}$ ' $\mathrm{l}$-qudat of Medina, though the sultan personally and pressingly urged him to accept it. ${ }^{123}$ Muhammad b. Baktūt al-Z̄āhirī (d. 735/1334), evidently a Qalandari mystic, was a master of calligraphy, a favourite field of activity and patronage in Mamluk and awsāa al-nās circles. ${ }^{124}$ "Alī b. Mankubars (d. 723/1323), a

119 On the negative economic consequences of this policy, see C. $\mathrm{H}$. Becker, 'Zur Kulturgeschichte Nordsyriens im Zeitalter der Mamluken', Isl. I (1910) 95 .

120 We find such cases in the formative period of Mamluk society and then, at times, when the supply of new Mamluks was impeded, e.g. after the visitations of the plague. M. H. Rabie, The Financial System of Egypt A.H. 564-74I/A.D. $1169-1341$ (London 1972), 59, gives a few isolated cases where this rule was abandoned.

121 The amir Nāṣir al-Din Muhammad b. Khațlubā who died in the battle of Hiṣn al-Akrād in 669/1270-1, was famous for his probity and his experience in financial affairs (al-Șafadī, III, ed. S. Dedering (Wiesbaden, and edn, 1974), 4If.). See also the vita of Dāwūd b. Asad al-Qaymarī, d. 763/ I 362 (Ibn Hajar, Ir, I86).

$122 \mathrm{~S}$. Labib, 'The problem of the bid' $a$ in the light of an Arabic manuscript of the 14th century', JESHO 7 (1964) 191-6; the book was written in $801 / 1397$ and has recently been published (1986) by the German Archeological Institute in Cairo as vol. IrI of its series Quellen zur Gescbicbte des Islamischen Ägyptens, ed. Labib. $77 \mathrm{f}$.

123 Al-Ṣafadī, vi, ed. S. Dedering (Wiesbaden I972), I64f.; Ibn Hajar, I,

124 Al-Șafadi, II, ed. S. Dedering (Wiesbaden, znd edn, r974), $256 f$. 
Sufi shaykh al-shuyukh who had spent an adventurous life in Mongol Iran, the Yemen and Syria, acquired fame in Cairo for his mastery in astrological divination; we owe to him a magic quadrant which allegedly helps to cure colic. ${ }^{125}$

Many sons of Mamluks were engaged in haditth, ${ }^{126}$ the queen of the religious sciences which required an excellent command of Arabic. One of them, Ahmad b. Balabān al-Ba labakkī (d. $764 / 1363),{ }^{127}$ permits us to grasp the strong influence of the Mamluk parental home on his own intellectual developement: his father, rather unusually, had changed his and his own father's Turkish names into 'Abd al-Rahmān and 'Abd alRahim, 'since all men are servants of the Lord of the worlds'; from him the son had certainly inherited his deep religious sentiment. Ahmad b. Muhammad b. Uzdamur (d. 74r/r 340), a cousin of the historian Ibn [Aybak] al-Dawādārī, is one of numerous mubadditbin of Mamluk stock in our period. ${ }^{128}$

Other awläd al-nās, for example the muhaddith Ahmad b. Alțunbā (Khațlubā) (d. 723/1323),129 or the former private soldier Ibn Damurtāsh (d. 723/I 323), 130 acquired a good name in the lofty craft of poetry. 'Alī b. Sūdūn al-Bāshbughāwì̀s (d. 868/1464) verses were memorized in Egypt as late as the seventeenth century. ${ }^{131}$ Those awläd al-näs who were involved in politics and obviously remained relatively close to the court seem to have had difficulty in mastering the standards of ariud

125 Mufaḍal b. Abi 'l-Faḍā'il, al-Nabj al-sadīd wa 'l-durr al-farīd fï-mā bäd tärïkb Ibn al- Amid, in S. Kortantamer, Ägypten und Syrien qwischen I3I7 und I34I in der Cbronik des Mufaddal b. Abi'l-Fadä il (Freiburg 1973), Igf. Arabic text, 89 f. German translation. See also M.W. Dols, The Black Death in the Middle East (Princeton 1977), $139 \mathrm{ff}$.

126 E.g. Khalīl b. Turunțāy, born 704/1304-5 (Ibn Hajar, II, I78); Zakarīyā' b. Arghūn al-M̄ārdīñ̄, dates unknown (ibid., II, 207); Muhammad b. Tughrîl, d. 737/1 336-7 (al-Ṣafadī, III, 172); Muhammad b. Țūlūbughā, second half of the eighth/fourteenth century (ibid., III, I76f.); Muhammad b. "Abd al-Raḥmān Aydamur, born 7 ro/ 3 IO-Ir (ibid., III, 243 f.). Aḥmad b. Aybak al-Dimyātīi, who died of the plague in $749 / 1348$, was an all-round scholar with a special interest in ḅadīth and law (ușül and fur $\tilde{u}$ ) (al-Șafadī, one of his friends, gives his vita, vI, 260). Many more awläd al-nās specialists in the religious sciences are recorded in the contemporary sources.

127 Ibn Hajar, I, 123.

128 Ibid., I, 270.

129 Ibid., I, IIS.

130 Al-Ṣafadi, I, ed. H. Ritter (Wiesbaden, 2nd edn, 1961, 232-6.

131 Brockelmann, GAL, II, I8. 
and style; the spiteful remarks of the biographers on the poetic exploits of the amirs Ahmad b. Mughultāy (d. 764/1 362-3), who was chamberlain in Aleppo, ${ }^{132}$ Muḥammad b. Baktāsh (d. 749/ I348), an unpleasant intriguer in Syrian political affairs, ${ }^{133}$ and Muhammad b. Bakhīl (d. 683/1284-5), governor of the city of Alexandria, ${ }^{134}$ would suggest such a connection. ${ }^{135}$

We find grammarians in their ranks ${ }^{136}$ and disciples of the exact sciences, such as Khalīl al-Ṣafadī's less famous brother Ibrāhim b. Aybak (d. 742/I 34r) who after an adventurous youth became an authority on mathematics, the law of inheritance, and sburüt. 137

The activities of the awläd al-nās encompass the entire spectrum between full and genuine Mamluk functions and total submersion in the local religious and scholarly life. About half of the awläd al-nās portrayed in fourteenth-century biographical dictionaries combined their academic career - which had brought them into the orbit of these works - with an army post. Some of them, like the muhaddith Ahmad b. Kushtughdi (d. 744/1 343$),{ }^{138}$ were private soldiers (jundî), others rose to the rank of amir ashara ${ }^{139}$ or even amir tablkbana, like the abovementioned Muhammad b. Baktāsh or Khalīl b. al-Barjumī (d. I49/1348), another victim of the Black Death who became

132 Ibn Hajar, I, 339; see above, n. I1 8.

133 Al-Șafadī, II, $255 \mathrm{f}$.

134 Ibid., II, $242 \mathrm{f}$.

135 Another unsuccessful poet of Mamluk descent was Ahmad b. Bilik, second half of the eighth/fourteenth century (ibid., vi, 280).

136 Abū Bakr b. Aydughdi, d. before 750/1350, one of the soldiers of the balqa (min awläd al-jund), had studied the grammatical works of Abū Hayyān and Ibn al-Sarrāj; al-Dhahabi praises him for his learning in the Arabic language and for his piety (Ibn Hajar, I, 47 I f.). For Ibrāhīm b. Aybak, see the following note. Rajab b. Qarājā, dates unknown, a man with bad handwriting and no gift for poetry, was nevertheless a specialist on grammatical rules (ibid., Ir, I99). Abü Bakr b. Mughulțāy, dates unknown, 'the grammarian' (ibid., I, p. 499).

137 Al-Șafadi, v, 330-7. Ahmmad b. Muhammad b. Baybars, d. 798/1395, was an expert in the science of time-keeping ("ilm al-miqät), Ibn Hajar, I, 276.

138 Ibid., I, 253.

139 E.g. Abū Bakr b. Aybak al-Husāmī, d. 756/1355 (ibid., I, 471) or the above-mentioned Dāwūd b. Asad (n. I2r). The amir 'Alä' al-Dīn 'Alī, son of a bajizb, became famed for his piety and learning; he is said to have compiled as many as seventy-five volumes of qas $\bar{a}^{\prime} i d$ in praise of the Prophet; al-Malik al-Nāșir bestowed an imrat ashara on him which he kept until his death; see al-Shujā ${ }^{-i}$ in Schäfer, Beiträge, 54. 
notorious among his contemporaries for his fervent partisanship of the teachings of Ibn Taymiyya. ${ }^{140}$

Inevitably, the social and institutional status of the awläd al$n \bar{a} s$ who found themselves between the two most powerful classes of contemporary society, Mamluks and urban notables, was highly volatile. Loyalties were easily exchanged. We hear of several important awläd al-nās who tried to free themselves from their political and military responsibilities and who embraced scholarship as their new way of life. Frustrations and disappointments were certainly as relevant for these changes of career as honest religious motives. Ahmad b. Almalik al-Jūkandār (d. 793/I39I), holder of a high office at court, gave up his imra in $779 / 1377-8$, frequented Sufi convents and died a mujawwir in Mecca. ${ }^{141}$ Khalīl b. Kaykaldī al- ${ }^{-A}{ }^{-3} \overline{1}$ (d. 760/I359), a specialist on usül al-badìth who was famous among his contemporaries for his encyclopedic mind in the Arabic and religious sciences, ${ }^{142}$ demonstrated his alienation from Mamluk military business by giving up the 'garment of war' (ziyy al-jund), ${ }^{143}$ the uniform of the halqa soldier, for the 'garment of figh'. And finally, Muhammad b. Jankalī b. al-Bābā (d. 74I/I 340), the son of a wjäfidī, a non-slave immigrant, ${ }^{144}$ had grown up in the very centre of power at al-Malik al-Nāșir's court ${ }^{145}$ but remained an amir only with repugnance. This interesting man overtly preferred contacts with pious and learned men to boring sessions with the other amirs and the Turks, as al-Ṣafadī formulates it. He became an admired expert in subjects as far afield as hadīth, medicine, music, and Arabic grammar. He had a special interest in the poetry of his time, shallow and crude as it appeared to the majority of contemporary critics with more orthodox aesthetic standards. So it is not at all surprising that he was a friend of

140 Al-Șafadī, xIII, 398-9; Ibn Hajar, II, 183.

141 Ibid., I, I I f. I have analysed his career in detail in 'The Sons of Mamluks as Fief-holders ..., 143.

142 Al-Șafadī, xIIr, 4IO-Is; Ibn Hajar, II, I79-82.

143 On this term, see Ayalon, 'Studies on the Structure of the Mamluk Army', BSOAS is (r953) 458 n. 2.

144 Al-Ṣafadī, II, 3ro-r 3; Mufadddal b. Abi 'l-Faḍāilil, Nabj, in Kortantamer, Agypten und Syrien, 266f. On the name of his grandfather al-Bābā (not Albābā), see al-Ṣafadī, x, 6r, ll. 3-2 (arranged under letter $b \bar{a}$ ).

$145 \mathrm{He}$ was related to the house of Qalāwūn; Ibn Hajar, I, 68. On his father, see ibid., II, 76f.; al-Șafadī, Ix, 219; al-Shujā̄ī, in Schäfer, Beiträge, I 79 . 
the oculist Ibn Dāniyāl (d. 710/r 310 ) who introduced novel literary techniques in his popular shadow plays, nor that he eulogized, and emulated, the vulgar poems of Ibn al-Hajiaj, the enfant terrible of fourth/tenth-century Baghdad. Al-Ṣafadī, who portrays this man with great sympathy, only seems to have found fault with his madbhab: Ibn Jankalī was a staunch Hanbalī and, in his later life, even turned to the teachings of Ibn Hazm of the well-nigh defunct Zāhiriyya. ${ }^{146}$

This instability of loyalties, however, was the prerequisite for the specific contribution by awläd al-näs to Mamluk cultural history. In order to be fully integrated into the surrounding society, the awläd al-nās felt compelled to take sides and to opt for one of the two heterogenous traditions in which they participated. As we have seen, the majority of those awläd al-näs who were deemed worthy to be recorded by contemporary 'ulama' biographers, chose the local, Syrian or Egyptian, identity. Only a very few endeavoured to preserve and to defend at least part of their parental Turkish heritage. One can note that the Egyptian awläd al-nās, with their relative proximity to the court and the centre of political gravity, seem to have retained closer ties to the Mamluk sphere than those who went through their formative period in Syria, the domain of traditional scholarly excellence and 'ulamä power.

Two historians belong to the small group of those awläd al$n \bar{a} s$ writers who were ready to show, and were proud of, their Mamluk roots. As already pointed out, the exoticism of their reports about the world of the Turks and Mongols gives their works additional appeal, at least to our modern eyes. The first is Ibn [Aybak] al-Dawādārī (d. after $736 / 1336$ ) and the second Abu 'l-Mahāāin Ibn Taghrîbirdī (d. 874/r469).

Ibn [Aybak] al-Dawādārī, a full-fledged Egyptian, ${ }^{147}$ is unique among the contemporary chroniclers in that he describes with so much detail and literary taste, and also so sympathetically,

146 The political significance of the Zähiriyya ends in the ninth/fifteenth century. Ibn Taghribirdī gives details about a Zāhirī revolt in Syria in the years 798-808/1 395-1406 with repercussions in Egypt; see I. Goldziher, Die Zabiriten. Ibr Lebrsystem und ibre Gescbicbte (Leipzig 1884), 194. On the conditions under which a formerly accepted madbhab loses its equal standing, see J. Schacht, An Introduction to Islamic Law (Oxford 1964), 67.

$147 \mathrm{He}$ contrasts his own Egyptian dialect with the language of the Syrians; see his Kanz al-durar wa-jämi al-ghurar, rx, ed. H. R. Roemer (Cairo r 960), 199, 1. 6, 201, 1. 8, and my comments in the introduction to vol. virr (Cairo 1971), 34. 
the legendary past of his Turkish forbears. He was of Mamluk origin through both his maternal and paternal grandfathers. ${ }^{148}$ He was proud of his Mamluk background; he emphasizes his proficiency in archery, ${ }^{149}$ a typically Mamluk art, and boldly ranks himself, by virtue of close family ties to Sultan Làjīn, as one of the $\bar{a} \bar{a} \bar{a} d$ al-nās, the noblest of Mamluks. ${ }^{150}$

The Mamluk split identity, namely to be a Turk and an Egyptian Muslim at the same time, is epitomized in Ibn [Aybak] al-Dawādārī's rendering of Chingiz Khān's exploits: Chingiz Khān, the lord of the Mongols and of the Turks, conquers the whole world, except Egypt and the lands of the west. The stunning Mamluk victory at 'Ayn Jālūt is foretold allegorically in Chingiz Khān's dream when the khān stands on top of the holy mountain of the Turks at the eastern borders of China and sees the sun, which was about to descend into, and remain in, his hand, slip away from him to the west. ${ }^{151}$ In another story, the shaman who has to chose between three Mongol leaders in the hour of affliction empties the bowl which Chingiz Khān had placed in front of his tent-carriage, except for a small residue in the western corner of the vessel ${ }^{152}$ - another foreboding of the battle at 'Ayn Jālūt. ${ }^{153}$ Ibn [Aybak] alDawādārī's pride in his membership of the Turkish-Mongol tradition is matched by his consciousness of forming part of the religious élite, as a result of which it is incumbent to defend orthodox Islam and its strongholds Egypt and Syria against all pagan and heretic adversaries. In a pointed and provocative remark, he states that the superstitions of the Arabs, the people of the Prophet, are none the less insipid than those of the Turks and the Mongols. ${ }^{154}$ This attitude certainly won him no friends in staunch 'ulama' circles. And indeed, with one or two excep-

148 Haarmann, 'Alțun Hōan', 8 f.

149 Kanz, IX, I 22.

150 Durar al-tijjān, 2-3, year 698.

151 Kanz, viI, ed. S. 'Āsshür (Cairo 1972), 232, ll. I1-I6; Durar, I2, year 628 (= fol. 206b), ll. 13-18.

${ }_{152}$ Kanq, vir, 234, ll. 4-5; Durar, 13, year 628 (= fol. 207a). See also Haarmann, 'Alțun Hōān', 27-9.

153 This vision of contemporary history is reminiscent of Ibn al-Nafis's report on the 'infidels (= Mongols) who had to punish this community', and on the 'countries which these infidels could not conquer'; see Meyerhof and Schacht, Theologus, 42-6 Arabic text, 66-70 English translation.

154 Durar, 3, year 6is (= fol. I98a), 1. 20; Haarmann, op, cit., 3if. 


\section{ARABIC IN SPEECH, TURKISH IN LINEAGE}

tions, ${ }^{155}$ he is passed over in the biographical dictionaries, though he knew personally many celebrities of his day, and his work was known to, and exploited by, later compilers such as al-Maqrīzī. 156

The case of Ibn [Aybak] al-Dawādārī demonstrates the latitudes of eccentricity and independence of mind which the awläd al-nās could enjoy as interpreters between Mamluk and 'ulamä' lore if only they were ready to use it.

Other awlād al-nās writing in the fourteenth century (NB the famous al-Ṣafadī, a Syrian) betrayed their Turkish background in the extraordinary quantity and completeness of Mamluk biograms, ${ }^{157}$ without necessarily being favourable to Turkish affairs or to the Mamluk class as a whole. As has been mentioned before, his prosopography, a main source also for this article, was a cherished item in the famous library of the fifteenth-century maecenas and general Yashbak. In an unpublished tadbkira, al-Ṣafadi goes into the linguistic rules of Turkish, ${ }^{158}$ yet otherwise his social ambience seems to have been limited to the clerks and scholars (and some dawädärs) of Upper Palestine, Syria, and Egypt. He presents himself as wholly assimilated to the standards of the autochthonous 'ulam $\vec{a}$. For him too, a cultured Mamluk was a rare exception.

Like Ibn [Aybak] al-Dawādārī, Ibn Taghrībirdī, who takes us into the fifteenth century, was not ready to abandon his Turkish affiliations and therefore attracted the critisicm of local 'ulam $\vec{a}$ of Arab-Egyptian stock. Al-Sakhāwī (d. 902/1497) labelled Ibn Taghribirdî, clearly with derogatory intent, as a Turk (though, ironically enough, Ibn Taghribirdi was actually of Greek extraction). ${ }^{159}$ Ibn Taghribirdi shared the cultural values of the local scholars. $\mathrm{He}$ is the one who reproachfully mentions Sultan

155 Al-Sakhāwĩ I'lān al-tawbïkh li-man dhamma abl al-tärïkh, ed. F. Rosenthal (Baghdad 1382/1963), 242, tr. in Rosenthal, A History of Muslim Historiography (Leiden, and edn, 1968), 455. Ibn Hajar also seems to refer to Ibn [Aybak] al-Dawādāin as al-Hāfiz Ibn Aybak when dating the death of Tashtamur al-Ṭabbākhī (23 Sha ${ }^{\circ}$ bān 73 I/r June 133 I); cf. his Durar, II, 32 I, no. 2019.

156 Haarmann, Quellenstudien, i 17.

$157 \mathrm{Al}$-Șafadi even had access to the royal family; see his biography of Ibrāhīm b. Muhammad b. Qalāwūn, a sayyidī who was called qissīs, 'priest', because of his piety; he died of smallpox in $738 / 1337-8, W \bar{a} f \bar{z}, \mathrm{VI}, \mathrm{I}_{3} 8$.

158 I owe this reference to Professor Wolfhart Heinrichs of Harvard University.

159 Popper, 'Sakhāwī's Criticism', $377 \mathrm{f}$. 
Inäl's incapacity to write his name properly in Arabic, his mispronouncing even the fatiha and his neglect of the basic commandments of Islam. ${ }^{160}$ Yet he remained firmly attached to his Turkish background. His father had been atäbak al- asäkir, chief executive of the dawla, and had owned numerous Mamluks himself. From him, the historian had inherited the intimacy with court affairs. He accompanied Sultan Barsbāy on his hunting parties and participated in the planning of military operations in the endless fights between the Mamluks and the Aq Qoyunlu Turcomans.

Unlike the other famous historians of the fifteenth century, Ibn Taghrïbirdi was thoroughly familiar with Mamluk customs and affairs. ${ }^{161} \mathrm{He}$ evidently saw his task as one of bridging the gulf between Turkish and Arab culture. He was trained in the Arab sciences, but also in horsemanship and warfare. He translated Turkish names into Arabic for his readers who knew no Turkish ${ }^{162}$ and even wrote, not least for people such as alSakhāwi, his most outspoken critic, a treatise on the intricacies of Turkish phonology; ${ }^{163}$ he held that the intellectuals of his age should at least be able to spell the name of their sovereigns properly. It is probable that his double competence was the reason for the jealousies which he attracted. Unfortunate phrases such as 'what else can be expected from a Turk' from al-Sakhāwî's mouth ${ }^{164}$ (who, incidentally, himself wrote a treatise, filled with baditth quotations, on archery, the Mamluk craft par excellence ${ }^{165}$ ) even added racial undertones to this contro-

160 See Schimmel's comments, 'Sufismus', 274 n. 2.

161 Popper, op. cit., 382, referring to al-Maqrīzī and Ibn Hajar.

162 See his expert statement on the Arabic meaning of the name Aghizlū, labu fam, 'the one with a mouth', in al-Nujūm al-zäbira, x, 167, ll. I I-I4, Cf. also the editor's note in al-Ṣafadī, xI, ed. Shukrī Fayșal (Wiesbaden r $98 \mathrm{r}$ ), 238 n. I.

163 See Flemming, ‘Šerīf, 88 n. 7I; van Ess, 'Ṣafadī-Splitter. I', Isl. 53 (1976) 249 ก. 17.

164 Al-Daw' al-lämi" li-abl al-qarn al-täsi', x (Beirut, 2nd edn, n.d.), 306. Cf. Popper, op. cit., 388.

165 Al-Qawl al-tāmm fī fadl al-ramy bi 'l-sibām, Brockelmann, GAL, II, 44 no. I6; R. Mach, Catalogue of Arabic Manuscripts (Yabuda Section) in the Garrett Collection. Princeton University Library (Princeton 1977), 410, no. 4759 (autograph); I have studied this manuscript during my stay in Princeton in spring 1987 and hope to present an analysis of its contents and of its relationship to Ibn Qayyim al-Jawziyya's K. al-Furüsiyya (Cairo I360/I94I) in the near future. 
versy between the autochthonous scholars and the bomines novi of Mamluk stock. As referred to at the beginning, this antiTurkish animosity can be traced back well into pre-Mamluk times and was to outlive the Ottoman and even the French occupations of Egypt.

Addendum (continuation of n. 57, p. 95 supra): The traditional, rather restrained appreciation of the Mamluk contribution to letters is voiced by $M$. Gaudefroy-Demombynes, La Syrie à l'époque des Mamelouks d'après les auteurs arabes (Paris 1923), CXVIII: 'Leur action littéraire est moins heureuse. Les maîtres de l'Egypte et de la Syrie savent à peine la langue d'Imrou 1 Qais et d'Abou Nouwas, et les plus lettrés d'entre eux se pâment en écoutant des distiques, auprès desquels les plus méchants vers des Mille et une nuits sont de la grande poésie.' 